\title{
Digital Divide and the Information and Communication Society in Spain
}

\section{José Manuel Robles}

Complutense University of Madrid, Spain

\section{Cristóbal Torres-Albero}

Autónoma University of Madrid, Spain

e-mail: cristobal.torres@uam.es

\begin{abstract}
Internet use is unevenly distributed among the population of most developed countries. The literature on the subject offers an abundance of evidence regarding the variety of factors that affect this type of inequality referred to as the Digital Divide. Taking Spain as a case study, our empirical goal in this paper is to put forward a model of analysis to improve our ability to predict the effect of a heterogeneous set of variables on the Digital Divide. This model uses as independent variables the Nationality (Immigrants and Spanish Citizens), gender, age, education level, employment status, size of habitat and regions. Our findings show that the level of education variable has the greatest weight in explaining the Digital Divide in Spain. On this basis, we address our second - theoretical - goal in this paper, namely, to discuss the inequalities brought about by the Digital Divide. To do so, we introduce the concept of third Digital Divide.
\end{abstract}

Key words: Information and communication society, Digital Divide, social inequalities, Internet, social participation.

\section{Introduction}

The growing use of the Internet has given rise to an interesting debate regarding the possibilities and risks brought about by this technology. One of risks most frequently mentioned is what is known as the Digital Divide. The academic debate on the Digital Divide has gone through several phases, first focusing on the causes and then on the consequences of the phenomenon. Initially, the focus was on the differences in access to the Internet, especially between wealthy and poor areas. In a second phase, academic interest shifted to the analysis of Internet use and, in particular, of the social groups with the lowest rates of use. More recently, there have been attempts to analyse to what extent the Digital Divide poses a threat to the balanced development of advanced societies. However, few studies have combined an analysis of the determining factors of the Digital Divide together with an examination of its consequences. 
The general goal of this paper is precisely to relate the determining factors of the Digital Divide with their social consequences. To this aim, we consider the explanatory variables most frequently used in the literature on the Digital Divide and we take Spain as a case study. Our goal is twofold. On the one hand, our empirical goal is to establish to what extent a model based exclusively on social, demographic and geographic variables is capable of predicting Internet use in Spain, while measuring the relative weight of each of the independent variables on the dependent variable. We conclude that our model has the explanatory power to account for, to a great extent, Internet use in Spain, and that citizens' level of education is the variable with the greatest weight.

Our second goal is to outline a set of hypotheses regarding the inegalitarian effects of the results shown in our empirical study, making reference to the work of authors such as Norris (2001.) or van Dijk (2005.). This second goal is theoretical in nature and consists in introducing a new concept of Digital Divide (Third Digital Divide) to helps us understand, not as much the current nature of this phenomenon, but its possible future consequences.

To meet the empirical and theoretical goals of this paper, we have proceeded as follows. In the following section, we reconstruct the chronological evolution of the concept of Digital Divide, showing the main approaches and explanations of this social phenomenon. This provides an outline of the theoretical background of our approach. In the third section we provide a brief description of the Digital Divide in Spain based on the series of surveys carried out by the Spanish National Institute of Statistics (INE) from 2004. to 2009. We apply the technique of logistic regression to the INE 2009. survey to control the effect of each of the social, demographic and geographic variables regarding use or lack of use of the Internet in Spain. In the fourth section, we outline the empirical goals of the paper and, on the basis of these goals, we reflect on the inegalitarian effects of the Digital Divide and the concept of the Third Digital Divide. This enables us to address our theoretical goals too.

\section{Theoretical Proposal}

In its original sense, the concept of Digital Divide refers to the differences regarding Internet access. Thus, the source of technological inequalities was identified as the differences in opportunities to access Information and Communication Technologies (ICTs) in general and the Internet in particular. This conception has been held by different Public Administrations and international institutions, such as for example the OECD (2000.), but it has also been widely accepted in academia.

Pioneering research on the subject carried out in the US focused on the differences in Internet access among different groups of citizens such as, for instance, the black population and the white population (Attewell, 2001.). However, it soon became evident that this type of inequality was mainly economic in nature (U.S. Department of Commerce, 2000.). Regardless of race or any other circumstance, poor American citizens were proportionally less likely to access ICTs than the rest of American 
citizens (Walsh, 2001.). From this point of view, one of the most fruitful lines of research has focused on the study of the differences in Internet access between rich and poor regions, countries or communities (Nicholas, 2003.; Chen and Wellman, 2004.a, 2004.b; Guillén and Suárez, 2005.). Influenced by this approach, the first conception of the Digital Divide focused mainly on the study of the impact of geographic and political variables (province, region or nation) on access and use of ICTs in general and the Internet in particular.

However, the conception of the Digital Divide as the difference between those who access and those who do not access the Internet has been subject to different criticisms and revisions. One of the most relevant criticisms was a result of the empirical ascertainment of the fact that the spread of infrastructures and services to provide Internet access did not guarantee the reduction of the Digital Divide (DiMaggio et al., 2001.). This led to academic interest shifting from the inequalities between those citizens who have and do not have access to the Internet to the differences between those who use and do not use this technology. It is what has been termed the Second Digital Divide (Bucy, 2000.; DiMaggio et al., 2001.; van Dijk and Hacker, 2003.; Hargittai, 2002.; Gunkel, 2003.). This new dimension of the Digital Divide made it evident that the differences in ICT use are determined by social variables, whether they are race-based (Hoffman et al., 2001.), gender-based (Bimber, 2000.; Cooper and Weaver, 2003.) or education-based (Bonfadelli, 2002.), as well as by another set of variables related with the ability to use the Internet (DiMaggio et al., 2004.; van Deursen and van Dijk, 2009.b).

In recent years, the study of the Digital Divide has turned its attention to more substantive aspects related with social inequalities and the effects of the Digital Divide. Authors such as van Dijk (2005.) have introduced a relational perspective of the Digital Divide in order to show that digital inequalities are a subset of social inequalities. From this point of view, the Digital Divide is determined by the same factors as other forms of inequality, that is, by variables such as level of education, gender, income, etc. But, in addition, the Digital Divide has the capacity to reinforce the distance that separates the most advantaged from the least advantaged citizens. In other words, unequal Internet use brings with it unequal participation in society. This circumstance leads to a reinforcement of the classical inequalities, as well as to an uneven distribution of the public and private resources available. Thus, this perspective prioritises the angle of the consequences of the Digital Divide on justice, equality and social inclusion (Warschauer, 2004.; Brennan and Johnson, 2005.), and the ethical repercussions (Rooksby and Weckert, 2005.) of this type of inequality. Norris (2001.) takes this same argument to the political sphere. According to this author, given the inequality in Internet access and use existing in Western societies, the political resources accessible through this technology empower those citizens with the drive and ability to take advantage of them, leaving behind those who do not make use of these resources.

We have referred to this approach to the study of digital inequalities as "the third dimension of the Digital Divide" (Robles et al., 2010.). We define this third level digital divide as the effects of the unequal distribution of Internet use on the set 
of relationships that define the social structure of a country. Thus, digital inequality is the result of the advantage gained by the most educated, youngest and most wealthy citizens by using the Internet as a means of improving their possibilities, compared to the least educated, least young and least wealthy citizens. It also refers to the effects of this advantage on the inequalities already existing in a given social and political community. From this point of view, the Internet is considered to be a resource that makes it possible to maximise the opportunities of citizens to take part and have recourse to socially valuable resources.

Closely related with this line of research is the concept of Digital Inequality. Academic interest in Digital Inequality has focused on looking at the different uses of the Internet that provide users with social, economic or political competitive advantages (van Deursen and van Dijk, 2009.a; DiMaggio and Bonikowski, 2008.; Hargittai and Hinnant, 2008.). The inequality arises between the users who obtain and those who do not obtain the advantages derived from the different uses of the Internet. However, the subject of our research is the general population and not the population of Internet users. There are two reasons for this. On the one hand, the persistence of what we have referred to as the second Digital Divide in Spain, as shown below, requires an analysis of the inequalities arising between citizens who use and citizens who do not use the Internet. On the other hand, the data from the INE do not allow us to study the inequalities between different groups of Internet users, but do provide sufficient basis for a study of the inequalities between those who use and those who do not use the Internet. Therefore, in order to meet our theoretical goals, we shall use the concept of third digital divide and shall leave for future research the study of the inequalities exclusively affecting the population of Internet users.

Having outlined the theoretical context, we proceed as follows. In the following section, we describe the state of the Digital Divide in Spain taking as the dependent variable "being or not being an Internet user" and as independent variables the following social, demographic and geographic variables: Nationality (Immigrants and Spanish Citizens), gender, age, level of education, employment status, size of habitat and Autonomous Community ${ }^{1}$ of residence. Likewise, and taking as reference the dependent and independent variables mentioned above, we apply a statistical analysis based on a linear logistic regression. With this test we seek to meet the empirical goals outlined in the introduction. These goals are: (i) to find out to what extent our model (independent variables) is robust enough for studying the digital divide in Spain; (ii) to verify whether all or some of the variables included allow us to predict Internet use in Spain; and (iii) to find out which of the variables under consideration has the greatest weight on our dependent variable. In the fourth section we provide a reflection regarding the accomplishment of these empirical goals and a theoretical discussion regarding their consequences, further explaining the concept of Third Digital Divide.

$\mathbf{1}$ Autonomous Communities are the regional units of political organization in Spain. 


\section{The Spanish Digital Divide}

The Information and Knowledge Society in Spain has evolved significantly in recent years $^{2}$. According to data from the Spanish National Institute of Statistics (INE), the evolution in ICT use has been very intense. Thus, for instance, the percentage of Spaniards who used the Internet in 2004 . was $40.4 \%$ of the population. By 2009., this percentage had risen to $59.8 \%$.

Despite the figures, ICT use in Spain is still today very unequal. As shown in table 1, the distribution of Internet users among the Spanish population is related with belonging to certain social groups. Thus, we can see the penetration of Internet use is higher among the most educated citizens, the youngest, students, people in work, men, and people who live in the richest and most developed geographical areas in the country and in the largest cities. Interestingly, there are no appreciable differences in Internet use among Spanish citizens and immigrant citizens.

Table 1

Internet Use in Spain according to social, demographic and geographic variables

\begin{tabular}{|c|c|c|c|c|c|c|c|}
\hline Year & & 2004 & 2005 & 2006 & 2007 & 2008 & 2009 \\
\hline \multirow[t]{2}{*}{ Gender } & Male & $44.9 \%$ & $49.0 \%$ & $51.5 \%$ & $55.8 \%$ & $60.7 \%$ & $63.4 \%$ \\
\hline & Female & $35.9 \%$ & $39.8 \%$ & $44.2 \%$ & $48.2 \%$ & $52.8 \%$ & $56.2 \%$ \\
\hline \multirow[t]{5}{*}{ Age } & $25-34 \mathrm{y} / \mathrm{o}$ & $57.6 \%$ & $64.7 \%$ & $66.7 \%$ & $72.6 \%$ & $78.3 \%$ & $80.1 \%$ \\
\hline & $35-44$ y/o & $43.9 \%$ & $48.8 \%$ & $54.3 \%$ & $57.1 \%$ & $63.7 \%$ & $68.2 \%$ \\
\hline & $45-54 \mathrm{y} / \mathrm{o}$ & $29.7 \%$ & $32.1 \%$ & $39.6 \%$ & $45.9 \%$ & $50.8 \%$ & $54.9 \%$ \\
\hline & $55-64 \mathrm{y} / \mathrm{o}$ & $13.7 \%$ & $17.3 \%$ & $17.9 \%$ & $21.1 \%$ & $24.6 \%$ & $29.1 \%$ \\
\hline & $65-74 \mathrm{y} / \mathrm{o}$ & $3.0 \%$ & $3.7 \%$ & $5.0 \%$ & $6.4 \%$ & $8.9 \%$ & $11.0 \%$ \\
\hline \multirow[t]{2}{*}{ Nationality } & Spanish & $40,6 \%$ & $44,3 \%$ & $47,9 \%$ & $52,0 \%$ & $56,7 \%$ & $60,0 \%$ \\
\hline & Immigrants & $38,5 \%$ & $46,5 \%$ & $46,7 \%$ & $52,0 \%$ & $56,8 \%$ & $58,0 \%$ \\
\hline \multirow[t]{6}{*}{$\begin{array}{l}\text { Level of } \\
\text { education }\end{array}$} & Illiterate & $0.1 \%$ & $0,8 \%$ & $0.0 \%$ & $0.4 \%$ & $0.4 \%$ & $0.6 \%$ \\
\hline & Primary education & $6.7 \%$ & $7,0 \%$ & $11.9 \%$ & $11.2 \%$ & $13.8 \%$ & $17.2 \%$ \\
\hline & $\begin{array}{c}\text { 1st phase secondary } \\
\text { education }\end{array}$ & $26.4 \%$ & $29,2 \%$ & $37.1 \%$ & $43.7 \%$ & $51.0 \%$ & $54.2 \%$ \\
\hline & $\begin{array}{c}\text { 2nd phase secondary } \\
\text { education }\end{array}$ & $61.2 \%$ & $64,8 \%$ & $66.7 \%$ & $71.6 \%$ & $76.3 \%$ & $78.3 \%$ \\
\hline & $\begin{array}{c}\text { Higher professional } \\
\text { education }\end{array}$ & $64.7 \%$ & $70,9 \%$ & $71.5 \%$ & $76.9 \%$ & $81,1 \%$ & $85.1 \%$ \\
\hline & Higher education & $83.1 \%$ & $85,5 \%$ & $87.9 \%$ & $89.3 \%$ & $91,7 \%$ & $92.4 \%$ \\
\hline
\end{tabular}

2 All the data included in this section is from the Survey regarding equipment and use of information and communication technologies in Spanish homes carried out by the Spanish National Statistics Institute (Instituto Nacional de Estadística -INE-) in the years 2004., 2005., 2006., 2007., 2008. and 2009., following the methodological guidelines of the European Union Statistics Office (EUROSTAT). In 2009., it was carried out by means of home personal interviews of a total of 24,935 citizens above the age of 15 . They are available at the following address: (http://www.ine.es/metodologia/t25/t25304506609.pdf). 


\begin{tabular}{|c|c|c|c|c|c|c|c|}
\hline Year & & 2004 & 2005 & 2006 & 2007 & 2008 & 2009 \\
\hline \multirow[t]{6}{*}{$\begin{array}{c}\begin{array}{c}\text { Employment } \\
\text { status }\end{array} \\
\end{array}$} & In work & $50.3 \%$ & $55.6 \%$ & $59.7 \%$ & $64.4 \%$ & $68.8 \%$ & $72.7 \%$ \\
\hline & Unemployed & $37.4 \%$ & $40.3 \%$ & $40.8 \%$ & $49.3 \%$ & $55.5 \%$ & $58.6 \%$ \\
\hline & Student & $89.9 \%$ & $92.4 \%$ & $94.7 \%$ & $95.9 \%$ & $97.2 \%$ & $98.4 \%$ \\
\hline & Housework & $9.1 \%$ & $8.3 \%$ & $14.5 \%$ & $16.7 \%$ & $19.0 \%$ & $22.2 \%$ \\
\hline & Retired & $5.9 \%$ & $7.0 \%$ & $7.3 \%$ & $9.4 \%$ & $13.8 \%$ & $16.9 \%$ \\
\hline & Other & $27.6 \%$ & $41.4 \%$ & $40.5 \%$ & $40.2 \%$ & $44.0 \%$ & $54.6 \%$ \\
\hline \multirow[t]{5}{*}{$\begin{array}{l}\text { Size of } \\
\text { habitat }\end{array}$} & $\begin{array}{c}\text { More than } 100,000 \\
\text { inhabitants }\end{array}$ & $33.2 \%$ & $37.0 \%$ & $51.3 \%$ & $49.5 \%$ & $54.7 \%$ & $49.3 \%$ \\
\hline & $\begin{array}{c}50,001 \text { to } 100,000 \\
\text { inhabitants }\end{array}$ & $47.1 \%$ & $49.9 \%$ & $41.5 \%$ & $59.1 \%$ & $48.6 \%$ & $53.6 \%$ \\
\hline & 20,001 to 50,000 inhabitants & $38.0 \%$ & $43.6 \%$ & $47.4 \%$ & $50.6 \%$ & $56.7 \%$ & $60.9 \%$ \\
\hline & 10.001 to 20,000 inhabitants & $35.8 \%$ & $42.0 \%$ & $42.5 \%$ & $46.3 \%$ & $50.5 \%$ & $55.7 \%$ \\
\hline & Up to 10,000 inhabitants & $30.5 \%$ & $33.4 \%$ & $36.0 \%$ & $40.8 \%$ & $46.6 \%$ & $49.9 \%$ \\
\hline \multirow[t]{12}{*}{ Regions } & Galicia & $37.7 \%$ & $43.1 \%$ & $48.6 \%$ & $51.2 \%$ & $57.2 \%$ & $60.3 \%$ \\
\hline & Asturias & $37.2 \%$ & $39.2 \%$ & $45.8 \%$ & $50.6 \%$ & $52.3 \%$ & $57.4 \%$ \\
\hline & Cantabria & $32.0 \%$ & $39.6 \%$ & $40.0 \%$ & $42.8 \%$ & $50.5 \%$ & $55.3 \%$ \\
\hline & Castilla León & $47.6 \%$ & $52.1 \%$ & $53.2 \%$ & $56.2 \%$ & $64.2 \%$ & $66.0 \%$ \\
\hline & Canary Islands & $38.3 \%$ & $42.0 \%$ & $45.7 \%$ & $49.9 \%$ & $55.6 \%$ & $60.5 \%$ \\
\hline & Valencia & $33.3 \%$ & $36.3 \%$ & $34.5 \%$ & $39.5 \%$ & $43.5 \%$ & $49.6 \%$ \\
\hline & Basque Country & $32.5 \%$ & $38.1 \%$ & $41.9 \%$ & $43.0 \%$ & $47.6 \%$ & $49.8 \%$ \\
\hline & Aragón & $49.5 \%$ & $54.9 \%$ & $58.6 \%$ & $63.8 \%$ & $67.0 \%$ & $67.8 \%$ \\
\hline & Navarra & $37.5 \%$ & $39.0 \%$ & $45.4 \%$ & $45.1 \%$ & $48.7 \%$ & $51.4 \%$ \\
\hline & Balearic Islands & $45.8 \%$ & $45.8 \%$ & $50.2 \%$ & $54.2 \%$ & $59.0 \%$ & $65.5 \%$ \\
\hline & Catalonia & $45.9 \%$ & $49.2 \%$ & $47.9 \%$ & $53.6 \%$ & $59.5 \%$ & $62.5 \%$ \\
\hline & Madrid & $42.2 \%$ & $42.7 \%$ & $46.4 \%$ & $49.3 \%$ & $56.1 \%$ & $53.6 \%$ \\
\hline
\end{tabular}

Source: INE. Own elaboration

The greatest differences are determined by citizens' age and level of education. It is also noteworthy that the differences among social groups within each variable considered continue to be in 2009., if not as significant as in 2004., certainly quite significant. Thus, despite the gap having reduced, there are still significant differences between young citizens and university educated citizens and the rest of Spanish citizens. As to Internet use by Autonomous Communities we find that between the most advanced communities and the communities with the lowest percentage of users, the difference is practically twenty percentage points. These differences, far from decreasing, have remained stagnant or even increased slightly over the last five years. This trend also applies to the size of habitat variable. 
The only variable in which we don't find this trend is nationality. In this case, there are no differences in Internet use among Spanish citizens and immigrants during the period studied. Since there is not a digital divide in this area, we will exclude this variable in our subsequent analysis.

The results obtained reveal an irregular distribution of Internet use which can be appreciated when taking a broad and heterogeneous set of social and geographic variables as a base. To meet the empirical goals established at the end of the previous section, we have developed a statistical model that uses the data from the latest survey (2009.) of the Spanish National Institute of Statistics (INE). Before providing an account of the results obtained, we provide an outline of this statistical method.

\subsection{Methodology and empirical results}

The statistical technique used was logistic regression, an analytical tool that is very useful to verify whether several independent variables determine the occurrence or not of a given event. Thus, the dependent variable is the use or non-use of Internet, considering, according to the INE's methodological definition, that users are those who have accessed the Internet at least once in the last three months ${ }^{3}$. The independent or explanatory variables introduced in the model are the following: gender (male, female), age (16-29, 30-44, 45-59, 60+), level of education (no formal education/primary education, secondary education, university education), employment status (in work, unemployed, student, housework, pensioner, other), size of habitat $(<10,000,10,000-50,000,50,000-100,000,+100,000$ and capitals $)$ and Autonomous Community (Andalusia, Aragón, Asturias, Cantabria, Castilla-La Mancha, CastillaLeón, Catalonia, Valencia, Extremadura, Galicia, Balearic Islands, Canary Islands, La Rioja, Madrid, Murcia, Navarra, Basque Country, Ceuta, Melilla).

The method of inclusion of variables chosen is forward conditional selection, in order to obtain the most parsimonious model. All the explanatory variables are categorical and are coded in the same order that appears in the previous paragraph, establishing for all of them the first category as reference. The inclusion of variables in the model was carried out in six steps. Therefore all the explanatory variables considered are significant. This does not mean that all the variables are relevant, given that significance depends on the size of the sample and, in this case, because the sample is so big, small differences are considered significant.

3 The dependent variable is a standard defined by the National Statistics Institute of Spain. This variable is also widely used in studies on the subject. We decided to keep this standard variable as the dependent variable because it allows us to analyze citizens who use the Internet with a high frequency (daily and weekly) and citizens who use the Internet at an average frequency (once a month and once every three months). Excluded so that citizens hardly use the Internet. We believe that, while the first two groups can be considered Internet users, not so with the second. 
With regard to the goodness of fit of the model, all the tests showed very satisfactory results. Firstly, with regard to the omnibus tests on the coefficients, which allow us to verify step by step the individual and joint contribution of the variables included in the model, we can say that both individually and jointly they are significant.

Table 2 shows different pseudo $\mathrm{R}^{2}$ values. These indicators are based on the model likelihood and should be taken with caution given that none of them explains the variance in a manner analogous to the $\mathrm{R}^{2}$ coefficient of the linear regression. What they do share with it is that they take values between zero and one, closer to one the better the fit. In the case under study, these indicators show very positive results.

Table 2

Summary of models

\begin{tabular}{ccc|c|c}
\hline \hline & -2 log likelihood & $\begin{array}{c}\text { Cox \& Snell R } \\
\text { squared }\end{array}$ & $\begin{array}{c}\text { Nagelkerke } R \\
\text { squared }\end{array}$ \\
\hline Step & 1 & 19255.609 & .328 & .439 \\
& 2 & 15764.360 & .438 & .585 \\
& 4 & 15010.382 & .459 & .613 \\
& 5 & 14834.680 & .464 & .620 \\
& 14772.304 & .466 & .622 \\
\hline
\end{tabular}

Source: Own elaboration based on 2009. data from the INE

To complete the information regarding the goodness of fit measures, the percentage of cases correctly classified is $82.8 \%$ (for a cut-off point of 0.5 ), with a rate of true negatives of $76 \%$, and a rate of true positives of $88.6 \%$.

Having verified the goodness of fit of the model, we go on to analyzing in what sense the social, demographic and geographic variables considered have an influence on Interne use (Table 3). To do so, we shall look at the categories showing significant differences compared to those established as reference and the coefficients shall be interpreted in terms of odds ratios ${ }^{4}$.

4 Odds are defined as the likelihood of occurrence of an event by the likelihood of nonoccurrence, that is, $\mathrm{P} /(1-\mathrm{P})$. In this case, the odds would be the ratio between the likelihood of using the Internet and the likelihood of not doing so. 
Table 3

\begin{tabular}{|c|c|c|c|c|c|c|c|c|}
\hline \multicolumn{9}{|c|}{ Variables in the Equation - Coefficients } \\
\hline & & & & & & & C.I. 95 & or $\operatorname{EXP}(B)$ \\
\hline & $\mathrm{B}$ & E.T. & Wald & $\mathrm{gl}$ & Sig. & $\operatorname{Exp}(B)$ & Lower & Upper \\
\hline $\begin{array}{c}\text { REGION } \\
\text { Andalusia (Ref.) }\end{array}$ & & & 154.321 & 18 & 0.000 & & & \\
\hline Aragón & 0.509 & 0.134 & 14.361 & 1 & 0.000 & 1.663 & 1.278 & 2.164 \\
\hline Asturias & 0.225 & 0.145 & 2.412 & 1 & 0.120 & 1.252 & 0.943 & 1.663 \\
\hline Cantabria & 0.485 & 0.189 & 6.593 & 1 & 0.010 & 1.624 & 1.122 & 2.351 \\
\hline Castilla-La Mancha & 0.191 & 0.111 & 2.935 & 1 & 0.087 & 1.210 & 0.973 & 1.505 \\
\hline Castilla-León & 0.162 & 0.102 & 2.503 & 1 & 0.114 & 1.176 & 0.962 & 1.437 \\
\hline Catalonia & 0.630 & 0.072 & 76.292 & 1 & 0.000 & 1.877 & 1.630 & 2.163 \\
\hline Valencia & 0.442 & 0.079 & 31.270 & 1 & 0.000 & 1.556 & 1.332 & 1.816 \\
\hline Extremadura & 0.015 & 0.146 & 0.011 & 1 & 0.917 & 1.015 & 0.763 & 1.351 \\
\hline Galicia & -0.146 & 0.098 & 2.200 & 1 & 0.138 & 0.864 & 0.713 & 1.048 \\
\hline Balearic Islands & 0.552 & 0.142 & 14.999 & 1 & 0.000 & 1.736 & 1.313 & 2.295 \\
\hline Canary Islands & 0.186 & 0.107 & 3.036 & 1 & 0.081 & 1.204 & 0.977 & 1.483 \\
\hline La Rioja & 0.005 & 0.250 & 0.000 & 1 & 0.983 & 1.005 & 0.615 & 1.642 \\
\hline Madrid & 0.467 & 0.078 & 36.146 & 1 & 0.000 & 1.595 & 1.370 & 1.858 \\
\hline Murcia & -0.216 & 0.126 & 2.946 & 1 & 0.086 & 0.806 & 0.630 & 1.031 \\
\hline Navarra & 0.431 & 0.185 & 5.421 & 1 & 0.020 & 1.539 & 1.071 & 2.214 \\
\hline Basque Country & 0.252 & 0.105 & 5.773 & 1 & 0.016 & 1.287 & 1.048 & 1.580 \\
\hline Ceuta & -0.329 & 0.564 & 0.340 & 1 & 0.560 & 0.720 & 0.238 & 2.173 \\
\hline Melilla & -0.030 & 0.494 & 0.004 & 1 & 0.952 & 0.971 & 0.369 & 2.554 \\
\hline $\begin{array}{c}\text { AGEG } \\
16-29 \text { (Ref.) }\end{array}$ & & & 906.081 & 3 & 0.000 & & & \\
\hline $30-44$ & -0.887 & 0.066 & 182.964 & 1 & 0.000 & 0.412 & 0.362 & 0.468 \\
\hline $45-60$ & -1.594 & 0.068 & 552.801 & 1 & 0.000 & 0.203 & 0.178 & 0.232 \\
\hline $60+$ & -2.626 & 0.098 & 711.987 & 1 & 0.000 & 0.072 & 0.060 & 0.088 \\
\hline $\begin{array}{c}\text { LEVED } \\
\text { No ed./Prim. (Ref.) } \\
\end{array}$ & & & 2395.240 & 2 & 0.000 & & & \\
\hline Secondary & 1.911 & 0.054 & 1265.834 & 1 & 0.000 & 6.762 & 6.087 & 7.513 \\
\hline University & 3.802 & 0.081 & 2205.583 & 1 & 0.000 & 44.797 & 38.224 & 52.500 \\
\hline $\begin{array}{c}\text { EMPSIT } \\
\text { In work (Ref.) } \\
\end{array}$ & & & 500.741 & 5 & 0.000 & & & \\
\hline Unemployed & -0.450 & 0.061 & 54.227 & 1 & 0.000 & 0.638 & 0.566 & 0.719 \\
\hline Students & 2.472 & 0.227 & 118.539 & 1 & 0.000 & 11.846 & 7.591 & 18.485 \\
\hline Housework & -1.137 & 0.075 & 232.397 & 1 & 0.000 & 0.321 & 0.277 & 0.371 \\
\hline Pensioners & -1.196 & 0.090 & 175.791 & 1 & 0.000 & 0.302 & 0.253 & 0.361 \\
\hline Other & -0.294 & 0.114 & 6.666 & 1 & 0.010 & 0.746 & 0.597 & 0.932 \\
\hline $\begin{array}{c}\text { HABITAT } \\
<10,000 \text { (Ref.) }\end{array}$ & & & 63.823 & 3 & 0.000 & & & \\
\hline $10,000-50,000$ & 0.291 & 0.060 & 23.164 & 1 & 0.000 & 1.337 & 1,188 & 1.505 \\
\hline $50,000-100,000$ & 0.391 & 0.082 & 22.558 & 1 & 0.000 & 1.478 & 1,258 & 1.737 \\
\hline$+100,000$ and Caps. & 0.453 & 0.057 & 62.057 & 1 & 0.000 & 1.572 & 1,405 & 1.760 \\
\hline GENDER (Ref. Male) & -0.276 & 0.044 & 38.642 & 1 & 0.000 & 0.759 & 0,696 & 0.828 \\
\hline Constant & -0.329 & 0.093 & 12.642 & 1 & 0.000 & 0.720 & & \\
\hline
\end{tabular}

Source: Own elaboration from 2009. data from the INE 
In summary, all the social and demographic variables considered show significant differences with regard to Internet use. Having said this, the magnitude of these comparisons varies depending on the characteristic under consideration. The geographic variables habitat and Autonomous Community, together with the gender variable, do not show differences as significant with regard to Internet use once the rest of the variables have been controlled, whereas level of education, age and employment status seem to be determining in explaining and understanding the digital divide.

To distinguish the significant from the relevant, we resort to concepts such as likelihood and deviance to assess the explanatory contribution of each variable included in the model. There are several procedures whose aim is to standardize the coefficients obtained in logistic regression models and thus be able to compare them and establish a "hierarchy" of variables according to their weight on the dependent variable. However, these methods are useful when the explanatory variables are metric and not categorical, such as in our case.

Given that likelihood measures the plausibility of a logistic regression model, it is essential to take it into consideration when attempting to measure its explanatory power. However, what is normally used is a transformation of likelihood ( $L=$ $2 \ln V)$ known as deviance from the model. Given that $L$ varies between 0 and 1 , its logarithm will always be negative, so the deviance will always be a positive figure. The more efficient a model, the higher its likelihood (closer to 1) and, therefore, the lower its deviance.

Based on these concepts - likelihood and deviance - we have valued the explanatory power of each variable included in the model. It should not surprise us that the null model (with no explanatory variables, only with the constant) shows the highest deviance and that, as the variables are included, the deviance reduces gradually. The reduction of the deviance as the variables are included in the model is proportional to the explanatory power of the variables, so that, if it the variable is significant, the deviance will reduce considerably when it is included. Similarly, when the explanatory power is low, so will be the reduction of deviance. We must point out that the explanatory power of each variable depends on the rest of variables included in the model, so our aim is not so much to see which variable determines to a greatest extent Internet use, but rather to quantify in some way what each variable explains about this use that is not explained by the other variables. To this aim, two deviances have been considered: that of the model with all the explanatory variables and that of the model with all the variables except the variable we are analyzing. The difference between both deviances gives us a measure of the explanatory power of the variable in question. These differences can also be measured with regard to the deviance of the model with all the variables, thus obtaining the percent increase experienced by the deviance when each of the variables is removed. 
Table 4

Explanatory Power of the Variables Included in the Model

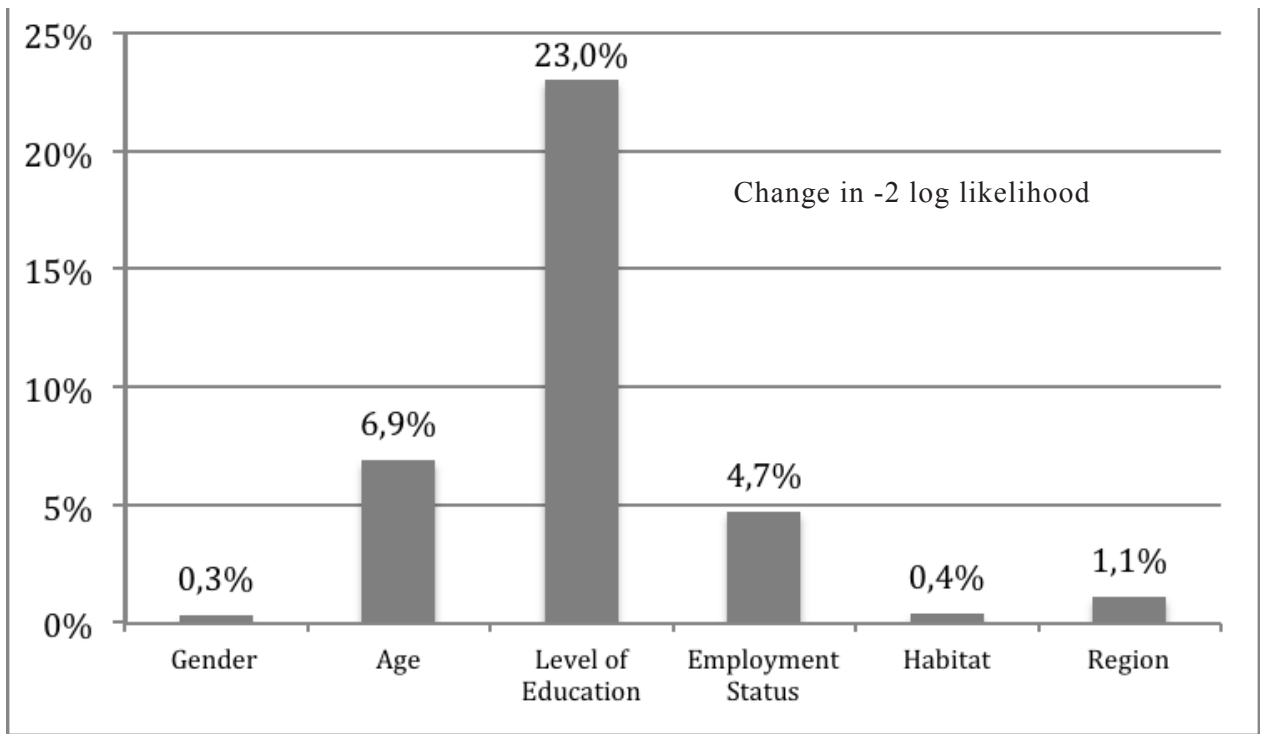

Source: Own elaboration based on 2009. data from the INE

The results shown on Table 4 confirm what we had pointed out above. That is, that although all the variables are significant, the plausibility of the model is not affected in the same way when we remove one variable or another. Citizens' age, employment status and, especially, level of education are variables with considerable explanatory power, with their removal from the model leading to a considerable reduction in the model's overall explanatory power. By contrast, individuals' gender and the characteristics of the geographic environment they live in, although significant, are variables with a practically negligible explanatory power.

\section{Discussion}

In this section we start by addressing the empirical goals set out above, before providing a theoretical analysis of the consequences of the Digital Divide for the case of Spain and of the more general idea of the third digital divide.

The empirical analysis based on geographic, social and demographic variables predicts, to a great extent, the likelihood of being or not being an Internet user in Spain. Our model, based exclusively on this type of variable, allows us to classify $82.8 \%$ of cases. Likewise, the $\mathrm{R}^{2}$ value obtained is also a very good indicator of our model's predictive capacity. In other words, addressing the first (i) of our empirical goals, our model is very well suited to the subject of study. 
The results offered in the previous section also address the second (ii) empirical goal. We have seen that all the variables considered in our model are significant. Thus, gender, age, level of education, employment status and place of residence (habitat and Autonomous Community) become variables which help predict Internet use in Spain and which, for the same reason, are related with the Digital Divide. These results position us with authors who, like DiMaggio et al. (2001.), approach the study of the Digital Divide from a sociological angle and attempt to understand to what extent variables of this kind explain the Digital Divide. Likewise, these results are very relevant from a theoretical point of view, as they allow us to verify, for the case of Spain, one of the fundamental theses of van Dijk (2005.): that the Digital Divide is a type of inequality of a technological nature whose determining factors coincide with those of other types of inequality. In other words, that the Digital Divide is determined by the same causes as classical inequalities.

Beyond these considerations, our study allows us, in the third place, to provide information regarding the third (iii) of our empirical goals in this paper. The conclusion that, for the case of Spain, the variable with the greatest weight on Internet use is citizens' level of education allows us to support the thesis of authors such as Bonfadelli (2002.) who point to level of education as a fundamental factor for explaining differences in Internet use.

Up to this point, our paper has allowed us to advance in the knowledge of the causes to predict Internet use or lack of use in Spain. However, this does not improve our understanding regarding the possible risks implicit in the Digital Divide. From our point of view, to advance in this direction it is necessary to appeal to a theoretical framework that allows us to order and interpret the information available. And this is where the concept of third digital divide (Robles et al., 2010.) comes in. Above, we defined the third digital divide as the effects of the unequal distribution of Internet use on the set of relationships that define the social structure of a country, in this case, Spain. We believe that these differences are a form of social exclusion in the sense of inaccessibility of an individual or group to the employment, economic, political and cultural possibilities others do have access to and enjoy (Castel, 1995.). We interpret the relationship between the Digital Divide and social exclusion based on the premise that the Internet is a valuable resource that allows users to access a larger volume of information, a broader network of social relationships, opportunities to access competitive resources or to improve communication with political representatives. In short, we consider the Internet to be a resource that increases citizens' real possibilities.

The empirical results of this paper allow us to establish the basis for a study of the Third Digital Divide. As shown here, Internet use in Spain is especially related with citizens' level of education. In other words, citizens with a medium or high level of education are considerably more likely to enjoy the possibilities offered by the Internet. From the opposite angle, citizens with a low level of education are less likely to take advantage of the possibilities offered by the Internet. Thus, level of education appears as the most determining barrier for a given set of citizens to access the "real opportunity" of improving their lives by using the advantages provided by the In- 
ternet. Thus, the Digital Divide becomes a mechanism of social exclusion when the inequality in access (first dimension of the digital divide) and use (second dimension of the digital divide) impact the possibility for citizens to access life-improving services (third dimension of the digital divide).

Thus, ICT use is not a direct cause of inequality. The fact that some citizens and not others use the Internet does not in itself cause social asymmetry. What make the Internet a potentially inegalitarian technology are the consequences associated with its use, the conjunction of this fact with the unequal distribution of access to it and the implications of all of this on the reinforcement of the social inequalities that define the social structure of a region (Rooksby and Weckert, 2005.). In short, the inegalitarian risks of ICTs are associated with the competitive advantages generated by their use and the specific characteristics of the groups that benefit from them.

Taking as reference van Dijk (2005.), we could say: (i) the social inequalities that affect a given society produce an unequal distribution of resources; (ii) an unequal distribution of resources leads to an unequal access to ICTs; (iii) unequal access and use of ICTs causes differences in social participation and engagement of the affected citizens; (iv) and, lastly, unequal participation and engagement in society implies a reinforcement or even a deepening of the inequalities in the distribution and use of the resources, as well as an increase or a reproduction of the social differences. Thus, the root of the social problem of the Digital Divide lies in the effect of the use of the Internet regarding the possibilities and advantages of certain social groups and, inversely, regarding the limitation of possibilities of other groups.

In our case study, these limitations affect mainly those citizens with lower levels of education and, to a lesser extent, citizens over the age of 45. This implies that the Digital Divide may lead to a significant increase of the fundamental inequalities that affect these social groups in Spain. For instance, as Norris (2001.) suggests, given the age and level of education of Internet users, it is possible to expect a digital culture that is particularly sensitive to post-materialistic values, which shall be the most common in the Internet. This fact could affect the political system in different senses. One of these senses is, according to Norris, the social promotion of this type of value compared to those of citizens who are not Internet users.

Along these lines, we can argue that the fundamental risk of the Digital Divide is related with the combination of the growing number of online services and tools that make it possible to access certain competitive advantages and the persistence of classical social inequalities which, like level of education, affect Internet use. This fact is especially problematic, as there is an increasing number of online services that do not have offline equivalents. This means that citizens who are not Internet users or who lack the necessary digital knowledge may not access them. This type of service ranges from spheres as important as employment (e.g. online job offers), home (e.g. cheaper rentals), political participation (e.g. digital democracy) or leisure (e.g. online flight offers). Therefore, the combination between Internet penetration and the social inequalities existing in a given territory is, from the point of view of social justice, dangerous. In our opinion, we could consider this understanding of 
digital inequalities as a Third Digital Divide, which is superimposed upon the First (access) and the Second (use) Digital Divide.

\section{Conclusion}

This paper aims to join the body of research that attempts to elucidate the nature and risks of the Digital Divide. Our aim has been to reinforce the idea that the Digital Divide is a consequence of the social inequalities that structure advanced modern societies and which are still a result of classical social variables (level of education, employment status, age, etc.). In this regard, we have shown in our case study how the differences in Internet use can be reduced to social differences, especially those due to the level of education of Spanish citizens. Thus, having or not having secondary or university education is the most significant factor in explaining the Digital Divide in Spain. Likewise, our empirical study has shown that even one of the most significant non-social variables in the polarisation of Internet use, the geographic Digital Divide, can be accounted for by social variables.

This paper has successfully reinforced the idea that the Digital Divide is another form of social inequality, but also, that it is a new form of social inequality. It emerged with the arrival of ICTs and their central role in the Information and Knowledge Societies. Its importance lies in the fact that, in this new form of economic and social development, the main source of productivity and social structurisation is the action of knowledge upon knowledge itself. And ICTs are the means by which information and knowledge is accessed, generated, processed and distributed in this new type of society (Castells, 1996.). Thus, the Digital Divide becomes a structuring factor of social inequality in new societies.

In sum, the Digital Divide is a central aspect in the development of the information and knowledge society. But it is not the only one. We have been working on the role of social representations of citizens in the promotion or inhibition of the development of this new type of society (Robles, 2005.; Torres-Albero, 2005.a, 2005.b). To understand how this psychosocial factor interacts with the Digital Divide will be another milestone in our future work.

\section{Acknowledgements}

This paper is part of the results obtained within the Research Projects CSO200917337 and CSO2009-13424 of the Spanish National Research Plan of the Ministry of Science and Technology and has the support of Gauss Center in the L.R. Klein Institute at Autónoma University of Madrid. We would like to thank Ellen Duthie for improving the use of English in this paper. 


\section{References}

1. Attewell, P. (2001). The First and the Second Digital Divides. Sociology of Education, 74 (3): 252-269.

2. Bimber, B. (2000). Measuring the Gender Gap on the Internet. Social Science Quarterly, 81 (3): 868-876.

3. Bonfadelli, H. (2002). The Internet and Knowledge Gaps. A Theoretical and Empirical Investigation. European Journal of Communication, 17 (1): 65-84.

4. Brennan, Linda L. and Johnson, Victoria E. (2005). Social, Ethical and Policy of Information Society. Hershey: Information Science Publishing.

5. Bucy, Erik P. (2000). Social Access to the Internet. Harvard International Journal of Politics, 5 (1): 50-61.

6. Castel, R. (1995). Les Métamorphoses de la Question Sociale. Paris: Librairie Arthême Fayard.

7. Castells, M. (1996). The Information Age: Economy, Society and Culture. Volume I: The Rise of the Network Society. Cambridge, Mass: Blackwell Publishers Inc.

8. Chen, W. and Wellman, B. (2004a). Charting Digital Divide: Comparing Socioeconomic, Gender, Life Stage, and Rural-Urban Internet Access and Use in Five Countries, in: W. H. Dutton et al. (Eds.). Transforming Enterprises. Cambridge, Mass: The MIT Press.

9. Chen, W. and Wellman, B. (2004b). The Global Digital Divide: Within and Between Countries. ITESociety, 1 (7): 39-45.

10. Cooper, J. and Weaver, Kimberlee D. (2003). Gender and Computers: Understanding Digital Divide. Mahwah: Lawrence Erlbaum Associates.

11. DiMaggio, P.; Hargittai, E.; Russel Neuman, W.; Robinson, J. P. (2001). Social Implications of the Internet. Annual Review of Sociology, 27: 307-336.

12. DiMaggio, P.; Hargittai, E.; Celeste, C.; Shafer, S. (2004). Digital Inequality: From Unequal Access to Differentiated Use, in: Kathryn M. Neckerman (Ed.). Social Inequality. New York: Russell Sage Foundation.

13. DiMaggio, P. and Bonikowski, B. (2008). Make Money Surfing the Web? The Impact of Internet Use on the Earnings of U.S. Workers. American Sociological Review, 73 (2): 227-250.

14. Guillén, Mauro F. and Suarez, Sandra L. (2005). Explaining the Global Digital Divide. Economic, Political and Sociological Drivers of Cross-national Internet Accesses. Social Forces, 84 (2): 681-708.

15. Gunkel, David J. (2003). Second Thoughts: Toward a Critique of the Digital Divide. New Media \& Society, 5 (4): 499-522.

16. Hargittai, E. (2002). Second Level Digital Divide: Differences in People's Online Skills. First Monday (Peer-Reviewed Journal on the Internet), 7 (4). (http://www. firstmonday.org/ issues/issue7 4/hargittai/).

17. Hargittai, E. and Hinnant, A. (2008). Digital Inequality Differences in Young Adults' Use of the Internet. Communication Research 35 (5): 602-621.

18. Hoffman, D.; Novak, Thomas. P. and Schlosser, Ann E. (2001). The evolution of Digital divide: Examining de Relationship of Race to Internet Access and Usage over Time, in: Benjamin M. Compaine (Ed.). The Digital Divide. Facing a Crisis or Creating a Myth?. Cambridge, Mass: The MIT Press. 
19. Nicholas, K. (2003). Geo-Policy Barriers and Rural Internet Access: The Regulatory Role in Constructing the Digital Divide. The Information Society: An International Journal 19 (4): 287-295.

20. Norris, P. (2001). Digital Divide? Civic Engagement, Information Poverty and the Internet Worldwide. Cambridge, UK: Cambridge University Press.

21. OECD (2000). Information and Technology Outlook. Paris: OECD.

22. Robles, José M. (2005). Las Creencias Cuentan: el Papel de la Percepción de la Utilidad de las TIC en el Desarrollo de la Sociedad de la Información, in: Diego B. (Ed.). TIC y Sociedad en el Siglo XXI. Granada: Editorial de la Universidad de Granada.

23. Robles, José M.; Torres-Albero, C. and Molina, O. (2010). La Brecha Digital. Un Análisis de las Desigualdades Tecnológicas en España. Sistema, 218: 3-22.

24. Rooksby, E. and Weckert, J. (2005). Digital Divides: their Social and Ethical Implications, in: Brennan, Linda L. and Johnson, Victoria E. (Eds.). Social, Ethical and Policy of Information Society. Hershey, PA: Information Science Publishing.

25. Torres-Albero, C. (2005a). La Ambivalencia ante la Ciencia y la Tecnología. Revista Internacional de Sociología (REIS), 42: 9-38.

26. Torres-Albero, C. (2005b). Representaciones Sociales de la Ciencia y la Tecnología. Revista Española de Investigaciones Sociológicas (REIS), 111: 9-43.

27. U.S. Department of Commerce (2000). Falling through the Net: Toward Digital Inclusion. Washington DC: U.S. Department of Commerce.

28. van Deursen, Alexander J.A.M. and van Dijk, Jan A.G.M (2009a). Improving Digital Skills for the Use of Online Public Information and Services. Government Information Quarterly, 26 (2): 333-340.

29. van Deursen, Alexander J.A.M. and van Dijk, Jan A.G.M (2009b). Using the Internet: Skill Related Problems in Users' Online Behaviour. Interacting with Computers, 21 (5): 393-402.

30. van Dijk, Jan A.G.M. (2005). The deepening divide. Inequality in the Information Society. Thousands Oaks, CA: Sage Publications.

31. van Dijk, Jan and Hacker, K. (2003). The digital divide as a complex and dynamic phenomenon. The Information Society: An International Journal, 19 (4): 315-326.

32. Walsh, Ekaterina O. (2001). The Truth about the Digital Divide, in: Compaine, Benjamin M. (Ed.). The Digital Divide. Facing a Crisis or Creating a Myth?. Cambridge, Mass: The MIT Press.

33. Warschauer, M. (2004). Technology and Social Inclusion: Rethinking the Digital Divide. Cambridge, Mass: The MIT Press. 
José Manuel Robles

Sveučilište u Madridu, Španjolska

Cristóbal Torres-Albero

Sveučilište u Madridu, Španjolska

e-mail: cristobal.torres@uam.es

\title{
Digitalna podjela i informacijsko i komunikacijsko društvo u Španjolskoj
}

\begin{abstract}
Sažetak
Upotreba Interneta je nejednako raspodijeljena među stanovništvom većine razvijenih zemalja. Literatura o toj temi nudi obilje dokaza o različitim čimbenicima koji utječu na tu nejednakost koju zovemo digitalnom podjelom. Uzimajući za primjer Španjolsku, empirijski cilj našega rada je prikaz analize kojom se povećava mogućnost predviđanja posljedica heterogenog niza varijabli na digitalnu podjelu. Ovaj model analize koristi kao nezavisne varijable nacionalnost (imigrante i građane Španjolske), spol, dob, stupanj obrazovanja, radni status, veličinu područja po broju stanovnika te različite regije. Naši rezultati pokazuju da je stupanj obrazovanja najznačajnija varijabla digitalne podjele u Španjolskoj. Na temelju toga bavimo se našim drugim, teoretskim ciljem, a to je rasprava o nejednakosti koju digitalna podjela uzrokuje. U tu svrhu uvodimo koncept treće digitalne podjele.
\end{abstract}

Ključne riječi: informatičko društvo i komunikacije, digitalna podjela, društvena nejednakost, Internet, društvena participacija. 